日植病報 $46: 209-215(1980)$

Ann. Phytopath. Soc. Japan $46:$ 209-215 (1980)

\title{
Serovars of Xanthomonas campestris pv. oryzae Collected from Asian Countries*
}

\author{
Jae Eul Chor ${ }^{* *}$, Nobuaki MAtsuy AmA** and Satoshi Wakimoto** \\ 崔 在乙**・松山宣明**・脇本 哲**：フジフの各国から \\ 収集した Xanthomonas campestris pv. oryzae の血清型*
}

\begin{abstract}
By means of gel diffusion test with antisera produced against Xanthomonas campestris pv. oryzae isolates Q7472 (pathogenic group I) and Q7502 (pathogenic group IV), three serovars, A, B-I and B-II, were designated in $X$. campestris pv. oryzae isolates collected from Asian countries. Among 160 isolates tested, 132 produced precipitin bands with both antisera and were designated as serovar A. The other 28 isolates gave bands with anti-Q7502serum but not with anti-Q7472-serum and were designated as serovar B. Serovar B was further separated into B-I and B-II, in terms of heat tolerance of antigen. Among 28 isolates belonging to serovar $B, 20$ fell into $B-I$ because they did not show any changes in reaction pattern even if heat treatment (dip into boiling water for $1 \mathrm{hr}$ ) was given to the antigens. The remaining 8 isolates were designated as B-II as they lost their antigenicity by heating.

The degree of autoagglutination of isolates in $0.1-10 \% \mathrm{CaCl}_{2}$ or $1 \%$ acriflavine hydrochloride solution closely related with serovars. Serovar B-I and B-II showed marked autoagglutination while serovar $A$ did not or much less in degree even if it occurred. The same phenomenon was also observed when heat treatment was given to the isolates suspended in $0.85 \% \mathrm{NaCl}$ solution.

Serovar $A$ is distributed all over Asian countries more widely with higher frequency as compared to serovar B.
\end{abstract}

(Received January 4, 1980)

\section{Introduction}

In regard to serological studies on Xanthomonas campestris pv. oryzae, some attempts were made to group isolates into strains by their serological characteristics. For this purpose, the agglutination test and gel diffusion test were commonly applied. In agglutination test, Fang et al..$^{6)}$, Mukoo and Isaka ${ }^{16)}$ and Mahanta and Addy's) reported that they could not find any distinct variations among $X$. campestris pv. oryzae isolates. By means of gel diffusion test, Addy and Dhal ${ }^{13}$ also reported similar results. Lin et al. ${ }^{11}$, however, showed an antigen correlated with virulence by gel diffusion test and the same result was obtained also by Addy and Dhal ${ }^{11}$.

At present, gel diffusion test has been applied most widely for analysing antigenic structures and serological grouping. By means of this technique, Grogan et al. ${ }^{8)}$ reported antigens species-specific for Pseudomonas syringae pv. lachrymans and $P$. syringae pv.

* Partially supported by Grant-in-Aid for Overseas Scientific Survey No. 404333 from the Ministry of Education, Science and Culture, Japan

** Faculty of Agriculture, Kyushu University, Fukuoka 812, Japan 九州大学農学部 
phaseolicola, and Lucas and Grogan ${ }^{13)}$ made clear at least three distinct serovars among $P$. syringae pv. lachrymans isolates. In Xanthomonas campestris pv. vesicatoria, two serovars based on the presence or absence of certain bands in gel diffusion test were designated by Charudattan et $a l^{4}$. De Boer et al. reported that the potato strains of Erwinia carotovora were able to be classified into 18 serogroups by diffusible somatic antigens detected by gel diffusion test ${ }^{5}$. For the purpose of detection and identification of some kinds of plant pathogenic bacteria, Obata and others ${ }^{17,18)}$ tested serological specificity among species of phytopathogenic bacteria and suggested that serological method was useful for identification of bacterial species and for diagnosis of the diseases.

To make clear the serological characteristics of $X$. campestris pv. oryzae, gel diffusion test was carried out by using many isolates collected from Asian countries.

\section{Materials and Methods}

Isolates. One hundred and sixty isolates of $X$. campestris pv. oryzae were used in this study. Of these isolates, 63 originated from Japan, 8 from Indonesia, 5 from India, 29 from the Philippines, 48 from Thailand and 7 from Vietnam. The isolates have been preserved at $-20 \mathrm{C}$ after freeze-drying.

Preparation of antigens. Each bacterial culture grown on PSA slant medium (potato decoction 1 liter, $\mathrm{Ca}\left(\mathrm{NO}_{3}\right)_{2} 0.5 \mathrm{~g}, \mathrm{Na}_{2} \mathrm{HPO}_{4} \cdot 12 \mathrm{H}_{2} \mathrm{O} 2.0 \mathrm{~g}$, peptone $5 \mathrm{~g}$, sucrose $15 \mathrm{~g}$, agar $15 \mathrm{~g}, \mathrm{pH} 7.0$ ) was suspended in $10 \mathrm{ml}$ of $0.85 \% \mathrm{NaCl}$ solution and washed two times by centrifugation at $8,000 \times \mathrm{g}$ for $20 \mathrm{~min}$. The precipitant was resuspended in the same solution and adjusted bacterial concentration at approximately $10^{8} \mathrm{cells} / \mathrm{ml}$. Each suspension was divided into three parts for giving treatments of heating in boiling water for $1 \mathrm{hr}$, sonication with Tominaga-150 ultrasonic vibrator for $20 \mathrm{~min}$ in ice box, and no treatment as a control. These antigen preparatons were used immediately after the treatment or stored at $-20 \mathrm{C}$ until needed.

Preparation of antisera. $X$. campestris pv. oryzae isolates Q7472 (pathogenic group I), Q7502 (pathogenic group IV) and N5837 were used for preparing antisera. Each bacterial isolate suspended in saline solution and sonicated bacterial suspension of the isolate Q7472 were injected 6 times into the ear vein of adult New Zealand white rabbits $(2.5-3.0 \mathrm{~kg}$ ) with doses increasing from 0.5 to $2 \mathrm{ml}$ at 4 -day intervals. Seven days after the final injection, the rabbits were bled and antisera were prepared by ordinary procedures. The antisera thus prepared were stored at $-20 \mathrm{C}$.

Serological agglutination test. Each bacterial suspension was mixed with different antisera serially diluted with saline solution in micro-precipitin tubes. The tubes were then incubated at $37 \mathrm{C}$ for $1 \mathrm{hr}$ and allowed to stand overnight at $4 \mathrm{C}$ before observation.

Gel diffusion test. Gel diffusion test was carried out in Petri dishes ( $10 \mathrm{~cm}$ diam.) plated with $10 \mathrm{ml}$ of $0.75 \%$ agar (special agar noble, Difco) in $0.01 \mathrm{M}$ potassium phosphate buffer ( $\mathrm{pH} 7.4$ ) containing $0.85 \% \mathrm{NaCl}$ and $0.04 \%$ azide. Wells for antigen and antiserum were cut in sets of six peripheral wells surrounding a center well with an agar gel cutter ( $4 \mathrm{~mm}$ diam.) keeping a distance of $6 \mathrm{~mm}$ from each other. The wells were filled either with antisera or with antigens and Petri dishes thus prepared were incubated at room temperature for $48 \mathrm{hr}$ until the precipitin bands appeared.

Autoagglutination test. The concentrated suspensions (ca. $10^{8}$ cells $/ \mathrm{ml}$ ) of each 

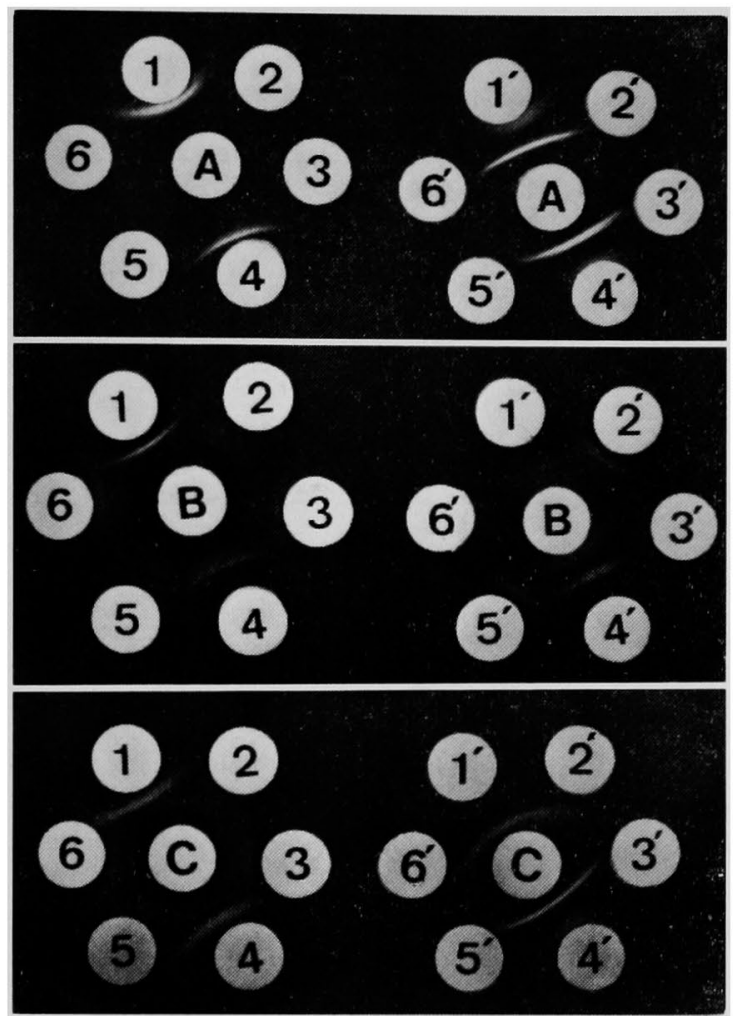

Fig. 1. Serological reactions of three different serovars of $X$. campestris pv. oryzae. Center wells A, B and C contain anti-Q7472 -serum, anti-Q7502-serum and antiQ7472 (sonic.)-serum, respectively. Outer wells were filled with whole cell suspensions in $0.85 \% \mathrm{NaCl}$ solution, i. e., the wells 1 and 4 contain the suspension of the bacteria belonging to serovar $A, 2$, 5 ; serovar B-I, and 3,6 ; serovar B-II. The wells $1^{\prime}, 2^{\prime}, 3^{\prime}, 4^{\prime}, 5^{\prime}$ and $6^{\prime}$ contain the cell suspensions of respective numbers heated at $100 \mathrm{C}$ for $1 \mathrm{hr}$ bacterial isolate in the solutions of $\mathrm{NaCl}$ $(0.85 \%), \mathrm{CaCl}_{2}(0.1-10 \%)$ and acriflavine hydrochloride ( $1 \%$ ) were incubated at room temperature for $6 \mathrm{hr}$. The degrees of agglutination were compared with each other. The effect of heat treatment (dipping into boiling water for $1 \mathrm{hr}$ ) on agglutination of the bacteria was also tested by using the same suspensions.

\section{Results}

One hundred and sixty isolates of $X$. campestris pv. oryzae showed different reactions against two kinds of antisera suggesting three serovars as shown in Table 1. Of these isolates, 132 isolates produced precipitin bands with both antiQ7472-serum and anti-Q7502-serum, were designated as serovar $\mathrm{A}$ The other 28 isolates, produced bands with anti-Q7502serum but did not with anti-Q7472serum, were designated as serovar $B$. Twenty isolates belonging to serovar $B$ were designated as B-I because they did not show any changes in reaction pattern even if heat treated antigens were used. The remaining eight isolates belonging to serovar B were designated as B-II because they lost their antigenicity by heating. All isolates produced precipitin bands with anti-N5837-serum but spur

Table 1. Serovars of $X$. campestris pv. oryzae in gel diffusion test

\begin{tabular}{|c|c|c|c|c|c|c|}
\hline \multirow{2}{*}{\multicolumn{2}{|c|}{ Serotype }} & \multirow{2}{*}{ Treatment } & \multicolumn{4}{|c|}{ Reaction to antiserum of } \\
\hline & & & Q7472 & Q7502 & N5837 & Q7472 (sonic.) \\
\hline \multirow{2}{*}{\multicolumn{2}{|c|}{ A }} & WC & + & + & + & + \\
\hline & & H & + & + & + & + \\
\hline \multirow{4}{*}{ B } & \multirow{2}{*}{ I } & WC & - & + & + & + \\
\hline & & $\mathrm{H}$ & - & + & + & + \\
\hline & \multirow{2}{*}{ II } & WC & - & + & + & + \\
\hline & & $\mathrm{H}$ & - & - & + & + \\
\hline
\end{tabular}

WC: Whole cell antigen, $\mathrm{H}$ : Antigen heated at $100 \mathrm{C}$ for $1 \mathrm{hr},+$ : Band formed, - : No band formed. 
Table 2. Homologous and heterologous agglutination reaction of three serovars of $X$. campestris pv. oryzae

\begin{tabular}{|c|c|c|c|c|c|c|c|c|c|c|c|}
\hline \multirow{2}{*}{ Antiserum } & \multirow{2}{*}{ Isolate } & \multicolumn{10}{|c|}{ Antiserum dilution } \\
\hline & & 20 & 40 & 80 & 160 & 320 & 640 & 1280 & 2560 & 5120 & 10240 \\
\hline \multirow{3}{*}{ Anti-Q7472-serum } & $\mathrm{Q} 7472^{*}$ & $H$ & $H$ & $H$ & $H$ & $H$ & + & - & - & - & - \\
\hline & Q7502 & $H$ & $H$ & H & + & + & + & + & - & - & - \\
\hline & N5837 & $H$ & $H$ & H & + & + & + & + & + & - & - \\
\hline \multirow{3}{*}{ Anti-Q7502-serum } & Q7472 & $H$ & $H$ & $H$ & + & + & - & - & - & - & - \\
\hline & Q7502* & $H$ & $H$ & $H$ & H & $H$ & + & + & + & - & - \\
\hline & N5837 & $H$ & $H$ & H & + & + & + & + & - & - & - \\
\hline \multirow{3}{*}{ Anti-N5837-serum } & Q7472 & $H$ & $H$ & + & + & + & - & - & - & - & - \\
\hline & Q7502 & $H$ & $H$ & + & + & - & - & - & - & - & - \\
\hline & N5837* & $H$ & $H$ & + & + & + & + & + & + & + & - \\
\hline \multirow{3}{*}{$\begin{array}{l}\text { Anti-Q7472 } \\
\text { (sonic.)-serum }\end{array}$} & Q7472* & $H$ & $H$ & $H$ & $H$ & $H$ & + & + & + & - & - \\
\hline & Q7502 & $H$ & $H$ & $H$ & $H$ & $H$ & + & + & + & - & - \\
\hline & N5837 & $H$ & $H$ & $H$ & $H$ & + & + & + & - & - & - \\
\hline
\end{tabular}

H: Complete agglutination, $+:$ Partial agglutination, - : No agglutination, $*$ : Homologous antiserumantigen reaction.

was observed between the bands produced by serovar $A$ and serovar $B$.

Sonication of bacterial cells changed their serological specificity. The antiserum against sonicated cells of the isolate Q7472 produced bands with intact cells of all the isolates tested (Fig. 1-C). When sonicated antigens were tested with anti-Q7472-serum, some isolates belonging to serovar B-I and B-II changed their serological properties.

Serological agglutination test was carried out with unheated antigens of each serovar. Although the titers of each antiserum somewhat varied depending upon the bacterial isolates used for titration, all the isolates belonging to

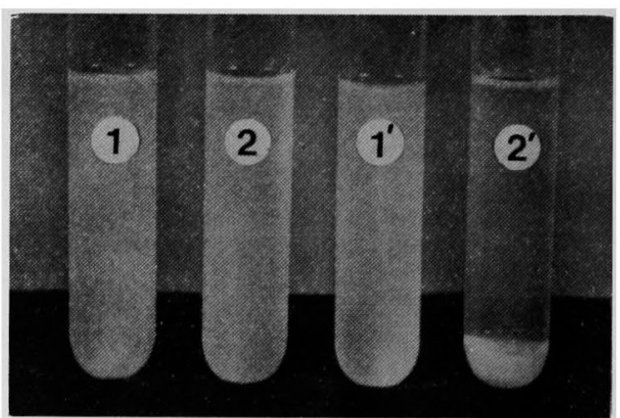

Fig. 2. Autoagglutination of $X$. campestris pv. oryzae in $0.85 \% \mathrm{NaCl}$ solution. 1 ; serovar A unheated, 2; serovar $B$ unheated, $1^{\prime}$; serovar $A$ heated at $100 \mathrm{C}$ for $1 \mathrm{hr}, 2^{\prime}$; serovar $\mathrm{B}$ heated at $100 \mathrm{C}$ for $1 \mathrm{hr}$. each serovar showed agglutination with four antisera without showing any specificity (Table 2).

Autoagglutination of the bacteria in the solutions of $0.1-10 \% \mathrm{CaCl}_{2}, 1 \%$ acriflavine hydrochloride and $0.85 \% \mathrm{NaCl}$ was observed. The effect of heating on the agglutination of each isolate was also tested in $0.85 \% \mathrm{NaCl}$ solution. The isolates belonging to serovar $B$ could be distinguished clearly from those belonging to serovar $A$, because the former showed marked autoagglutination. In the case of serovar A, autoagglutination did not occur or much less in degree even if it occurred (Table 3).

The isolates belonging to serovar $\mathrm{A}$ are distributed more widely in Asian countries as compared to those belonging to serovar B. The isolates belonging to serovar B were not detected so far among the isolates from India and Vietnam. 
Table 3. Autoagglutination in the solutions of various reagents

\begin{tabular}{|c|c|c|c|}
\hline Reagent & Serovar A & Serovar B-I & Serovar B-II \\
\hline Distilled water & - & - & - \\
\hline$" \quad(\mathrm{H})$ & + & + & + \\
\hline $0.85 \% \mathrm{NaCl}$ & + & + & + \\
\hline$" \quad(\mathrm{H})$ & + & H & m \\
\hline $0.1 \% \mathrm{CaCl}_{2}$ & + & 体 & $H$ \\
\hline $1 \%$ & + & $\mathrm{HH}$ & HH \\
\hline $10 \%$ & + & H & $\mathrm{HH}$ \\
\hline $1 \%$ Acriflavine hydrochloride & + & H & 世 \\
\hline
\end{tabular}

Wf: Complete autoagglutination, + : Partial autoagglutination, - : No autoagglutination, $\mathrm{H}:$ Heated at $100 \mathrm{C}$ for $1 \mathrm{hr}$.

Table 4. Serovars of $X$. campestrts pv, oryzae isolates

\begin{tabular}{|c|c|c|}
\hline Serovar & Origin & Isolate \\
\hline A & $\begin{array}{l}\text { Indonesia } \\
\text { India } \\
\text { Philippines } \\
\text { Thailand }\end{array}$ & $\begin{array}{l}\text { Q7418, Q7424, Q7428, Q7447, Q7467, Q7472, Q7464, Q7484, Q7512, Q75114, } \\
\text { Q7644, Q7649, Q7653, Q7647, Q7657, Q7660, Q7667, Q7670, Q7673, Q7781, } \\
\text { N5701, N5710, N5801, N5805, N5818, N5824, N5831, N5834, N5846, N5850, } \\
\text { N5854, N5861, N5863, N5879, N5881, N5843, N5802, Tokai, Ibaraki, } \\
\text { Yoshioka, H5809, H5809-SR, T7147, T7133, T7174, H75373, H75304 } \\
\text { N6901-1, N6803-1, 2, 1-2, Ku7811, Ku7812, Ku7813 } \\
\text { India5, India25, N6914, N6910, N6916 } \\
\text { PXO12, PXO15, PXO19, PXO25, PXO26, PXO29, PXO32, PXO43, PXO44, } \\
\text { PXO54, PXO60, PXO63, PXO64, PXO65, PXO66B, PXO73, PXO81B, } \\
\text { Ku7820, Ku7821, Ku7822, Ku7823, Ku7824, Ku7825, Ku7826, B-69 } \\
\text { TB7226, TB7234, TB7245, TB7246, TB7309, TB7310, TB7312, TB7409, } \\
\text { TB7412, TB7422, TB7423, TB7507, TB7509, TB7517, TB7523, TB7525, } \\
\text { TB7538, TB7613, TB7615, TB7622, TB7633, TB7639, TB7702, TB7706, } \\
\text { TB7712, TB7713, TB7715, TB7719, TB7802, TB7803, TB7804, TB7809, } \\
\text { TB7810, TB7815, TB7816, Ku7801, Ku7802, Ku7804, Ku7805, NO1, NO2 } \\
\text { B21B1, B2A1, B2B6, B2B10, B2C3, B2C4, Ku7505 }\end{array}$ \\
\hline I & $\begin{array}{l}\text { Japan } \\
\text { Indonesia } \\
\text { Philippines } \\
\text { Thailand }\end{array}$ & $\begin{array}{l}\text { Q7502, Q7512, N5806, N5829, N5842, N5816, N5847, N5859, N5875, H5809 } \\
\text { (Ku), Kagawa } \\
\text { Ku7813 } \\
\text { S-2, S-24, } 4 \\
\text { TB7236, TB7302, TB7540, TB7525, TB7806 }\end{array}$ \\
\hline II & $\begin{array}{l}\text { Japan } \\
\text { Philippines } \\
\text { Thailand }\end{array}$ & $\begin{array}{l}\text { N5833, N5845, N5868, N5837, Shiga2 } \\
\text { B-70 } \\
\text { TB7205, TB7721 }\end{array}$ \\
\hline
\end{tabular}

\section{Discussion}

Although marked differences were not observed among the isolates of $X$. compestris pv. oryzae in serological agglutination test, three serovars were detected in gel diffusion test. 
Since the intact bacteria cannot immigrate inside gel, the precipitates observed in gel diffusion test suggest that bacterial cells exude some diffusible antigens which easily migrate inside gel. By using sonicated cells, many bands appeared in gel diffusion test, which suggests the liberation of some kinds of antigens tightly combined within cell structures by the treatment. Sonicated bacteria, however, are considered to be unrecommendable for serotyping $X$. campestris pv. oryzae, because they did not show clear-cut specificity in gel diffusion test. The reliable method for serotyping $X$. campestris pv. oryzae was considered to analyze diffusible somatic antigens exuded from the cells as already reported on Rhizobium strains by Gibbins ${ }^{7)}$ and on Erwinia carotovora by De Bore et al. ${ }^{5)}$

The bacterial cells belonging to serovar $\mathrm{B}$ caused autoagglutination in $0.85 \% \mathrm{NaCl}$, $0.1-10 \% \mathrm{CaCl}_{2}$ and $1 \%$ acriflavine hydrochloride but those belonging to serovar $\mathrm{A}$ did not or much less in degree even if it occurred. According to the reports by Kropinski et al. ${ }^{9,10)}$ autoagglutination patterns in $4 \% \mathrm{NaCl}$ and $1 \%$ acriflavine proved to be useful for distinguish rough mutant of Pseudomonas aeruginosa from its wild-type strain. This technique was also used by Lindberg et al. in order to differentiate smooth strain from rough strain of Salmonella. ${ }^{12}$ ) Some kinds of cations are considered to play important roles in bacterial autoagglutination. ${ }^{2,3)}$ The elements necessary to autoagglutination of $X$. campestris pv. oryzae are not known, but supposingly they might be polysaccharides and/or proteins. The effect of cations on these elements may be different depending upon serovars, that is, very strong activation may be seen on the elements of serovar B but not on those of serovar A.

With regard to geographical distribution of the serovars, serovar A is distributed more widely with higher frequency in Asian countries as compared to serovar B. Serovar B was not detected from India and Vietnam in this experiment, however, further experiments using more number of isolates will be needed to make conclusion.

Since $X$. campestris pv. oryzae shows at least three serovars in gel diffusion test, one has to be cautious in identification of this bacterium by serological techniques.

\section{Acknowledgement}

We wish to express our hearty thanks to the staff members of Department of Plant Pathology and Entomology, National Institute of Agricultural Sciences, Japan, Division of Environment, Kyushu National Agricultural Experiment Station, Japan, Department of Plant Pathology, the International Rice Research Institute, the Philippines, Division of Plant Pathology and Microbiology, Department of Agriculture, Thailand, and Department of Pests and Diseases, Central Research Institute for Agriculture, Indonesia, for their kind supply of the bacterial isolates and collaboration in collecting isolates in those countries.

\section{Literature cited}

1. Addy, S. K. and Dhal, N. K. (1977). Indian Phytopath. 30:64-69.

2. Belcourt, A., Kroely, F. and Frank, R. M. (1974). J. Biol. Buccle. $2: 189-198$.

3. Cauldwell, C. B., Henkart, P. and Humphreys, T. (1973). Biochemistry $12: 3051-3055$.

4. Charudattan, R., Stall, R. E. and Batchelor, D. L. (1973). Phytopathology $63: 1260-1265$.

5. De Boer, S. H., Copeman, R. J. and Vruggink, H. (1979). Ibid. $69: 316-319$.

6. Fang, C. T., Reu, H. C., Chen, T. Y., Faan, H.C. and Wu, S.C. (1957). Acta Phytopath. Sinica $3: 99-124$. 
7. Gibbins, L. N. (1967). Can. J. Microbiol. 13:1375-1379.

8. Grogan, R. G., Lucas, L. T. and Kimble, K. A. (1965). Phytopathology 55 : 1060 (Abstr.).

9. Kropinski, A. M. B. and Chadwick, J. S. (1975). Can. J. Microbiol. 21 : 2084-2088.

10. Kropinski, A. M., Chan, L. C. and Milazzo, F. H. (1979). Ibid. $25: 390-398$.

11. Lin, B. C., Li, C. C. and Kuo, T. T. (1969). Bot. Bull. Acad. Sin. Taipei $10: 130-133$.

12. Lindberg, A. A., Sarvas, M. and Mäkelä, P. H. (1970). Infect. Immunity $1: 88-97$.

13. Lucas, L. T. and Grogan, R. G. (1969). Phytopathology 59 : 1908-1912.

14. Luderitz, O., Staub, A. M. and Westphal, O. (1966). Bacteriol. Rev. 30:192-255.

15. Mahanta, C. and Addy, S. K. (1977). Int. J. Syst. Bacteriol. 27 : 383-385.

16. Mukoo, $H$ and Isaka, M (1964). Ann. Phytopath. Soc. Japan $29: 13-19$.

17. Obata, T. (1968). Res. Bull. Pl. Prot. Japan 5:7-16.

18. Obata, T. and Tsuboi, F. (1972). Ibid. $10: 9-16$.

19. Otta, J. D. and English, H. (1971). Phytopathology $61: 443-452$.

\section{和文 摘 要}

\section{アジフの各国から収集した Xanthomonas campestris pv. oryzae の血清型}

崔 在乙・松山宣明・脇本 哲

イネ白葉枯病菌菌株のらち，病原型 I 群に属するQ7472菌とN 群に属するQ7502菌株の抗血清を使用し て，フジフ各国から収集したイネ白葉枯病菌の血清学的性質を寒天ゲル内拡散法にょって倹討した結果，3 つの血清型に大別することがでさた。供試160菌怢のうち，132菌怢は抗-Q7472-血清お゙よび抗-Q7502-血清 の両者と反応し，これを血清型 $\mathrm{A}$ と命名した。他の28菌株は後者に対してのみ反応し，これを B 型とした。 B型に含まれる28菌株の5ち，20菌株はそれらの抗原を熱処理 (100 C, 1 時間) しても反応性を失わなかっ たが，8菌株は熱処理することにより抗原性を失った。したがって前者をB-Iとし，後者をB-IIとした。

血清型B-IおよびB-IIに属する菌株の慜濁液は0.1-10\% $\mathrm{CaCl}_{2}, 1 \%$ acriflavine hydrochloride 液中で顕 著な自己凝集反応を示したのに対し，Aに属する菌株はほとんどその反応を示さなかった。また同様の現象 は0.85\% NaCl 液に䅗渴した細菌液を $100 \mathrm{C}, 1$ 時間熱処理した場合にも認められ，抗原因子と自己凝集因子 との関連性が示装された。 